\title{
Competing discourses of the forest shape forest owners' ideas about nature and biodiversity conservation
}

\author{
Tuomo Takala $^{1}$ (D) $\cdot$ Teppo Hujala ${ }^{1,2} \cdot$ Minna Tanskanen $^{3} \cdot$ Jukka Tikkanen $^{1}$
}

Received: 14 July 2018 / Revised: 27 July 2019 / Accepted: 6 August 2019 / Published online: 17 August 2019 (C) The Author(s) 2019

\begin{abstract}
Competing discourses of the forest guide forest-owners' ideas about the proper forest use and about the need to conserve biodiversity. In this paper, we examine how five predefined forest discourses (re)produced by Finnish forest owners treat nature and biodiversity conservation. Our critical discourse analysis combines qualitative content analysis with quantitative multivariate methods (NMDS). The data consists of in-depth interviews with 24 Finnish forest-owners. The five forest discourses formed a gradient from an absence of nature issues to a profound ecological pondering with deep affection and responsibility for nature. The discourses in between these two ends of the gradient contained narration on personal experiences but lacked the moral responsibility and deep theorizing typical of the nature-oriented discourse. The nature-oriented discourse proposed forest uses where the needs of nature were raised to a determining role whereas the other four discourses adhered to the standard economy-driven forest management paradigm. Both nature and the forestowners with a strong relationship with nature appeared marginalised in the prevailing order of the forest discourses. The discoursal conditions that we evidenced did not favour biodiversity conservation among forest-owners. The results thus call for active forest policy that aims to transform the prevailing order of the discourses, but also tries to overcome the discoursal hinders for biodiversity conservation within the prevailing order.
\end{abstract}

Keywords Human-nature relationship · Non-industrial private forest-owner · Forest-owner typology $\cdot$ Critical discourse analysis $\cdot$ Conservation social sciences

Communicated by David Hawksworth.

This article belongs to the Topical Collection: Forest and plantation biodiversity.

Electronic supplementary material The online version of this article (https://doi.org/10.1007/s1053 1-019-01831-7) contains supplementary material, which is available to authorized users.

Tuomo Takala

takala.tuomo.o@gmail.com

Extended author information available on the last page of the article 


\section{Introduction}

Most conservation problems have human reasons and we need both natural and social sciences to resolve them (Bennett et al. 2017; Teel et al. 2017). In this paper, we illustrate new kind of social reasons behind the persistent biodiversity loss in the Finnish forests with the aid of critical discourse analysis. Over 2100 red-listed species (754 NT, 465 VU, 250 EN, $118 \mathrm{CR}, 88 \mathrm{RE}, 458 \mathrm{DD}), 31,9 \%$ of all red-listed species in Finland, live primarily in forest biotopes (Hyvärinen et al. 2019, pp. 38-39) and 76\% of natural forest biotopes are classified as threatened (VU, EN, CR) (Kouki et al. 2018). The main reasons behind the biodiversity loss - the decrease of old-growth forests, old trees and deadwood, as well as changes in tree-species composition-are related to the intensive even-aged forestry practiced for decades (Hyvärinen et al. 2019, pp. 38-39). The state of species diversity has also become worse in comparison with the previous assessment in 2010 (Hyvärinen et al. 2019, pp. 111-112), even if retention trees at clear cutting areas and prescribed burns have helped individual taxa, such as beetles (Coleoptera) and true bugs (Heteroptera) (Juslén et al. 2016).

In many European countries and United States, a substantial part of forestland is owned by private persons and families (Pulla et al. 2013; Butler et al. 2016). In Finland, this share is $60 \%$ of the productive forest area (Luke 2018), making this owner group a very pivotal one from the perspective of biodiversity conservation. Although forest industries and professionals have an essential influence on forestry practices in Finland, forest-owners have the eventual power to decide and choose between management options on their land. The recent liberalisation of Finnish forest legislation (Ministry of Agriculture and Forestry 2014) increased the forest-owners' freedom more still.

High appreciation for biodiversity, pristine forests and other nature values is usually measured in Finnish forest-owner surveys (Horne et al. 2004; Paloniemi and Tikka 2008; Hallikainen et al. 2010). Furthermore, a multi-objective forest-owner type is the most common type in the dominant Finnish forest-owner typology (Favada et al. 2009). Sustainability issues have also a strong foothold in the national forest policy rhetoric (e.g. Horne et al. 2004; Ministry of Agriculture and Forestry 2015). These findings indicate that there is a significant inconsistency between the biodiversity data and the forest-owners' expressed values, objectives and attitudes. Obviously, we do not still know all those social and mental factors that hinder biodiversity conservation in the Finnish society. Critical discourse analysis could provide a valuable new perspective for this puzzle.

Discourse analysis has been mentioned as one of the principal method families within the conservation social sciences (Crandall et al. 2018), but we should not regard a discourse analysis as a method only. In the critical discourse analysis that we apply in this study (Fairclough 2010), it is the theory of intersubjective meaning-making and discoursal power that makes the method useful and unique. There are numerous studies that examine forest-owners' tendency, willingness or capability to conserve biotopes or species, officially or informally, with or without economic incentives (e.g. Bieling 2004; Horne et al. 2004; Paloniemi and Tikka 2008; Fischer and Bliss 2009; Hallikainen et al. 2010; Eriksson 2012; Primmer et al. 2014; Zorondo-Rodríguez et al. 2014; Mitani and Lindhjem 2015; Nzau et al. 2018; Vainio et al. 2018). Many of these studies also recognise the essential role that landowners' social environment plays in the conservation activities, but critical discourse analysis adds an important component of discoursal power into the analysis. Indeed, critical discourse analysis could be utilised more within the conservation sciences because of its capacity to reveal hidden power relationships and social inequalities that 
sustain conflicts and practices harmful for biodiversity conservation (Smith 2006; Sumares and Fidélis 2011).

In this study, we analyse those conditions that competing discourses of the forest (forest discourses) create for biodiversity conservation among Finnish forest-owners. Our approach is novel in two ways. First, there are no previous critical analyses on forest-owners' forest discourses (Takala et al. 2017a, b). This means that we do not know how the discoursal environment affects conservation in private forests. Previous critical discourse analyses on forest issues are few in the global North and concentrated on gender issues (Lidestav and Sjölander 2007; Leipold 2014; Holmgren and Arora-Jonsson 2015) and participatory decision-making processes (Arnold et al. 2012). Second, we examine conservation and nature issues in relation to all other meanings of the forest i.e. we do not compel forest-owners to treat those issues in our study. This means that a forest discourse can also lack conservation and nature issues altogether, if these are regarded as unimportant.

This paper is the third and the final part of our enquiry into Finnish forest-owners' discourses of the forest. In the first part, we identified five forest discourses (Takala et al. 2017a). The order of these discourses in relation to discoursal power was analysed in the second part (Takala et al. 2017b). In this third part, we ask (1) what kind of relationships the five forest discourses have on nature (forest species, biotopes, biodiversity) and (2) how are nature and different types of forest-owners positioned in the prevailing order of the discourses. With the aid of these two questions we aim to describe the prevailing discoursal conditions for biodiversity conservation in which Finnish forest owners live and make decisions. In the discussion part, we give policy recommendations based on our results.

\section{Theoretical framework}

\section{Critical discourse analysis}

Our critical discourse analysis follows the critical realist theory developed by Norman Fairclough (2010). Following this tradition, discourses are seen as one semiotic form of social practice that can constitute other components of social as well as material and mental realities while simultaneously constituted by them (Fairclough 2010, pp. 230-254). For example, we assume that linguistic, intersubjectively produced forest discourses have an effect on material forests and forest-owners' mental structures and vice versa. By forest discourse we mean a set of meanings and ways of speaking that presents its own kind of truth about the forest, the forest-owner and the proper way to use the forest. Importantly, these discourses need not include any narration on nature or conservation, if these issues do not belong to the essential meanings of the forest. This enables us to assess the importance of nature in relation to socio-cultural and economic meanings of the forest in the forest discourses.

In the first part of this study project, we identified the discourses of (1) the forester, (2) the economist, (3) the distant economist, (4) the critical anti-economist, and (5) the dutiful forest-owner (Takala et al. 2017a). The discourses were named following the ideal forest-owner types produced by each of them. Emphasis on economic versus non-monetary meanings of the forest and a weak versus a strong confidence on a forest-owner's own forest management skills formed the two main gradients separating the discourse types. In this paper, we examine the forest discourses' relationships with nature and biodiversity conservation. 
The intersubjective nature of discourses means that an individual forest-owner cannot produce an entire forest discourse alone. However, forest owners participate in the reproduction and transformation of discourses when they write and speak about the forest. Forest discourses also form a resource that an individual forest-owner can use when constructing their personal ideas about the forest. People typically adhere to discourses and to alternative truths provided by the discourses unconsciously as a natural part of their everyday lives (Fairclough 2010, pp. 69-83, 126-145). However, they can be empowered to recognize discoursal processes.

Our analysis is exclusively based on the shared meanings of forest-owners' linguistic narratives; we did not record actual forestry activity of the forest-owners or examine their personal mental structures. However, when discourses are based on actual forest-owners' narrations regarding forest-ownership and material practices, we assume that strong connections exist between the discourses, the actual forest-owners' mental structures and the actual material practices in the forest. These premises and assumptions are not exceptional, but this way to conceptualize and explain the connections between text and society are fundamental to socially oriented discourse analyses (van Dijk 1993; Fairclough 2010, pp. 167-201).

In the critical discourse analysis, special attention is paid to the social consequences of discoursal power. Power relations between competing discourses produce a considerably permanent order of discourses that sets actors in socially, societally or materially favourable and unfavourable positions. It has been stated that revealing social inequalities and showing alternative ways of thinking and acting are the most important goals of critical discourse analysis (Fairclough 2010, pp. 230-254). The critical orientation thus means that an analysis is committed to social equality as fundamental value. However, in studies that operate within the boundaries of nature and culture like this, the social commitment alone seems inadequate; we therefore add the perspective of ecological responsibility to our critical discourse analysis. These commitments also affect the style in which the results are discussed, as we aim to view the world from the perspectives of those suppressed by the prevailing order of discourses. This makes a clear difference to the value-neutral reporting style within positivist and postpositivist research tradition.

In the second part of this study project, the discourses of the economist and the forester were interpreted as hegemonic, illustrating simultaneously the hegemony of an economic truth about the forest and its proper use among the forest-owners (Takala et al. 2017b). The other three discourses were found to be marginalized in the order of the forest discourses. In this third part, we examine the consequences that this order has for biodiversity conservation and for forest-owners with different relationships with nature. Importantly, it is the ideal forest-owner types produced by the forest discourses that we analyse as subjects, not the actual 24 forest-owners that produced our empirical data. However, the discourses and the ideal types were derived from the narratives of the actual forest-owners; each of whom thus reflects the ideal types in their personal ways (Takala et al. 2017a). Alternatively, nature that we treat as a subject in our analysis is derived from the ecological sciences.

\section{Nature, relationships with nature and representations of nature}

The term nature and its countless collateral concepts refer usually to the nature that is either (1) external (the non-human world), (2) universal (the entire physical world), (3) intrinsic (the essence of something) or (4) super-ordinate (an inherent force) (Castree 2014, p. 10). In this study we operate with the external nature concept and mainly 
through the concepts of biodiversity, species and biotopes. Importantly, the term forest is not used as a synonym for nature.

We adopt the idea that the only way to make sense of nature is through representations (Castree 2014, pp. 3-68). Even if we acknowledge that the material nature external for human beings exists, we can only reach it through human translation and interpretation. An individual's idea of the forest is thus essentially and unavoidably based on those continuously produced representations of nature that they intentionally or unintentionally encounter in their everyday life (Castree 2014). We thus deal with the representations of the external nature in the five forest discourses and analyse the potential effects of these representations on yet another external nature represented by the ecological sciences (Fig. 1). Our critical analysis and the related aim of ecological responsibility necessitates that we include the ecological representation of nature from outside the five forest discourses into our analysis, and presume that this representation gives us the most accurate knowledge of the actual structures and processes of the material nature that we can find.

Treating the nature, represented by the ecological sciences, as one subject is a coarse generalisation, as there are numerous species and biotopes that are placed in different positions in the prevailing forest management culture. For example, Scots pine (Pinus sylvestris) is apparently doing well in the prevailing Finnish forests whereas many species dependent on deadwood and old-growth forests are suffering (Juslén et al. 2016; Hyvärinen et al. 2019, pp. 41-49). We therefore use the species and ecosystem level biodiversity as a measure for the well-being of the complex external nature in this work. An alternative option would, of course, to select some target species as a subject and analyse the social-ecological system from its specific perspective (e.g. Taylor and Carter 2013; Lischka et al. 2018).

The term human-nature relationship refers here to the relationship that an ideal forest-owner and, simultaneously, a discourse has with the external material nature (with forest species, biotopes and biodiversity). Importantly, a forest-owner's or a discourse's

\section{Nature of species and biotopes external for human beings}

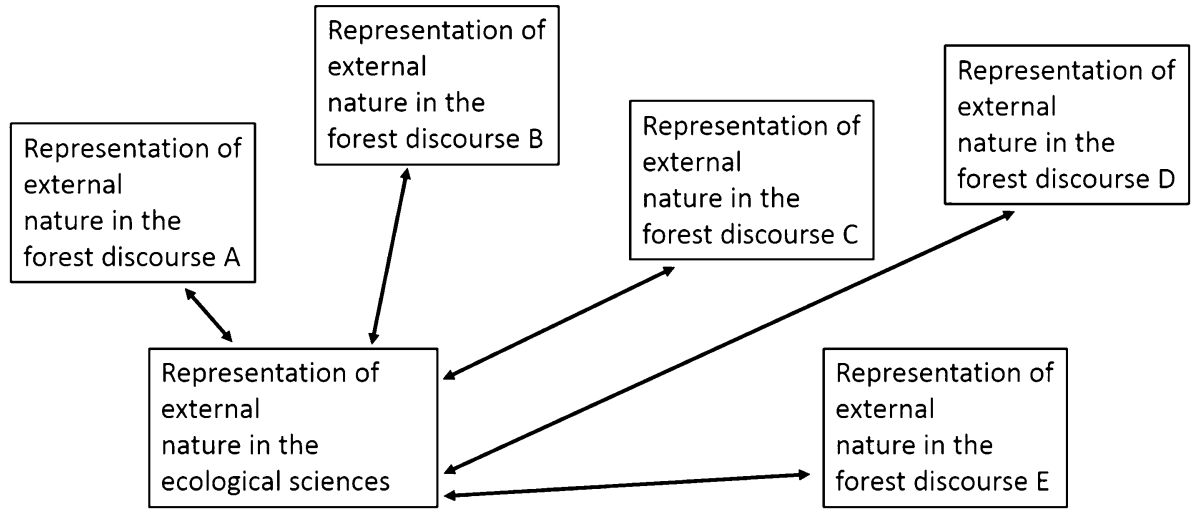

Fig. 1 The nature and its representations in this study. We first analyse the representations of the external nature in the five forest discourses (A-E) that simultaneously illustrate the ideal forest-owners' relationships with nature. The congruence between these five nature representations and the nature representation produced by the ecological sciences are then compared in order to find the potential ecological effects of the discourses. The potential effects are mediated through the ideal forest-owners' decisions and practices 
relationship with forest does not need to include the meaning of forest as nature i.e. a relationship with nature is not used as a synonym for a relationship with forest.

Flint et al. (2013) identified three broad classes along which human-nature relationship has been conceptualized and analysed in empirical typologies: (1) the respective positions of humans and nature, (2) the character of the bond between humans and nature, and (3) humans' understanding of nature. Following this categorization, we concentrate on the bond between humans and nature and on the understanding of nature. To be more precise, we analyse the ideal forest-owners' awareness of, affection for, responsibility for and interaction with the external nature of species and biotopes. Our premise is that a strong relationship with nature entails not only awareness of but also affection for nature and moral responsibility that is realised through material forest use. Instead, we do not examine whether the ideal forest-owners raise humans above nature or vice versa, or whether they feel themselves as a part of nature (positionality). It is also worth emphasising that we do not examine how forest-owners define the concept of nature.

Our analysis of human-nature relationships and of the ecological consequences of these relationships sustain the dualism between nature and humanity/culture that is commonly criticised within human geography (Castree 2014, pp. 137-144). This dualism has been seen as unrealistic and restrictive, and more sensitivity to hybridity and unclear boundaries have been demanded (Sundberg and Dempsey 2009; Castree 2014, pp. 137-144). However, dualisms and other polarized categorizations can also be seen as a human way to understand the world and, in this respect, we regard the human-nature dualism as much a necessity as the sensitivity to hybridity. For example, we could not examine the ecological effects of the discourses or the human-nature relationships without this dualism in this study. At the same time, we need to see beyond the dualism-the actual forest-owners' forests, for example, cannot be analysed as anything else than as the hybrids of culture and nature.

\section{Materials and methods}

\section{Study area, forest-owner sample and interview data}

This study is based on thematic interviews with 24 Finnish forest-owners from the municipalities of Joensuu, Liperi and Kontiolahti in the province of North-Karelia in Eastern Finland. The forest area on the property was under five hectares for the eleven of the forestowners and more than five hectares for the remainder thirteen forest-owners. The owners in these two groups were randomly selected from the forest estate database of the Finnish Forest Centre. Six women and 18 men participated as the primary interviewees and their mean age was 56 years (range 30-75). The spouse of an interviewee attended the interview in five cases.

In the thematic interviews, the 24 forest-owners produced narratives of their own forests and forest-ownership. A forest-owner was first asked to talk about their forest spontaneously, after which they were asked to continue based on a list of predefined themes. These themes were broad meaning categories for forest-like "wood resources", "recreation", "nature" and "forest economy"- and the forest-owner was let to choose those themes they wanted to discuss (Takala et al. 2017a). In the end of the interview, the interviewer asked whether the forest-owner was willing to talk about those themes they passed over in the previous phase. The interviewer was allowed to facilitate the forest-owner's narration by 
making non-leading comments and gestures typical of normal discussion, while any kind of manipulation, criticism or questioning was avoided. The average duration of an interview was around $50 \mathrm{~min}$ (range 40-80 $\mathrm{min}$ ).

In the province of North-Karelia over 55\% of the forestland is privately owned and only $3 \%$ is officially excluded from wood production (Finnish Statistical Yearbook of Forestry 2014). The percentage of private forests is lower and the percentage of preserved forests higher in the focus region than in southern Finland generally. Socioeconomically, the study area can be regarded as a representative example of the semi-peripheral regions found throughout Finland. There is one town, Joensuu, in this region surrounded by sparsely populated rural areas and small municipality centres. More detailed descriptions on the forestowner sampling, the study area and the interview settings (including the interview guide) can be found in Takala et al. (2017a).

\section{Analysis}

The interview data was first transcribed and coded. In the qualitative coding, we identified different details from the forest-owners' narratives that seemed to separate the forestowners, like different meanings of the forest, different ways of speaking or different ways to use the forest. The narratives were first read through and new codes were created from the details while reading. In total 153 codes were created in this first round of reading. In the second round of reading, the presence of these 153 codes in each narrative was examined and recorded in a binary (0-1) data matrix (forest-owners' narratives in rows and the codes in columns). Ninety-eight (98) of these codes were included in the NMS ordination analysis (Non-metric Multidimensional Scaling) where we analysed the multidimensional code structure of the narratives. The excluded codes were either pseudo-replicates for some included codes or then overly general, ambiguous or very exceptional in our data.

In the NMS, the co-occurrences of the codes in the narratives were transformed into the proximities between the codes in n-dimensional ordination space i.e. the codes that cooccurred often in the narratives were close to each other in the ordination graph (McCune and Grace 2002, pp. 125-142). For example, if the codes C1 and C2 in Table 1 were always found in the same narratives, they would be found close to each other in the ordination graph. Similarly, the forest-owners (narratives) that had similar code structure were situated close to each other in the ordination space. A two-dimensional NMS was selected in our case. This first phase of the analysis was common to all parts of this study project, and the full code list can be found in Takala et al. (2017a).

In the analysis of human-nature relationships we first sought for all those codes that were related to nature (forest species, biotopes and biodiversity external for human beings) in our list of 153 codes. In total 22 nature-related codes were found, and our analysis concentrated specifically on 15 codes that were included into the NMS (Table 1). The position of these 15 codes in the ordination space was then examined. Because the same data and NMS were applied in the previous analyses (Takala et al. 2017a, b) we could also assign the nature-related codes into the wider forest discourses and examine them in relation to discoursal power. The seven omitted codes were either overly rare $(\mathrm{C} 13, \mathrm{C} 16, \mathrm{C} 17$ in Table 1$)$ or very common $(\mathrm{C} 11, \mathrm{C} 14)$ in the narratives; or were interpreted as too equivocal or unclear to be included $(\mathrm{C} 4, \mathrm{C} 7)$.

After the examination of the code positions in the ordination space, expression of the codes in the forest-owners' narratives was analysed further qualitatively. At this stage we were also able to interpret how awareness of, affection for and responsibility towards nature 
Table 1 Nature-related codes

\begin{tabular}{ll}
\hline C1 & Recognizes sites in one's own forest that are important for nature or rich in biodiversity \\
C2 & Considers nature in forest management by some special measures \\
C3 & Tells about nature observations \\
C4 & Tells about the species outside the animal kingdom \\
C5 & Recognizes the value of old-growth forests for nature \\
C6 & Recognizes the importance of deadwood to nature \\
C7 & Regards nature as important \\
C8 & Speaks spontaneously about nature \\
C9 & Forest is primarily nature \\
C10 & Regards nature conservation as a threat, problematic or pointless \\
C11 & Fungi or insects cause problems \\
C12 & Recognizes special species living in one's own forest \\
C13 & Natural regeneration is caring for nature \\
C14 & Elk cause problems \\
C15 & Special affection/respect for nature \\
C16 & Legislation on nature conservation does not work \\
C17 & Has a special place in the forest that is a conservation site or a site for nature experiences \\
D7 & The prevailing forest management destroys nature and landscape \\
L5 & Regards climate change or extreme weather as a threat \\
L16 & Feels that a tree or a forest has to be cut at some predefined age \\
L17 & There is no need to worry about nature/landscape as the forest grows back \\
L25 & There is no hurry to cut an old-growth forest \\
\hline
\end{tabular}

The codes in bold font were included in the NMS

was manifested in the forest discourses. The ideal forest-owner's interaction with the forest and nature was also analysed in this phase.

In the following "Results" section we first examine the position of the 15 nature-related codes in the ordination space and analyse whether the two ordination dimensions can separate these codes and different human-nature relationships. After this, we present concise descriptions of the representations of nature (the ideal forest-owners' relationships with nature) in the five discourses. The interpretations are illustrated with the aid of citations (free translations from Finnish). Besides the comments of the forest-owner (F), the comments of the interviewer (I) or the forest-owner's spouse (FS) are included when necessary. Natural breaks in speech are marked with four dots, omitted non-relevant parts of the text with three dots in parentheses (...). Square brackets mark necessary additions. The 24 forest-owners are specified by an ordinal number and whether they own more $(\mathrm{m})$ or less (1) than five hectares $(\mathrm{m} 1-\mathrm{m} 13,11-111)$. Four of the 24 citations are the same as those used in Takala et al. (2017a, b). 


\section{Results}

\section{Nature-related codes in the NMS}

The fifteen nature-related codes that were included in the NMS were primarily distributed along Dimension 2 (y-axis) (Fig. 2). The codes that represented connectedness to nature $(\mathrm{C} 15, \mathrm{~L} 25)$, responsibility for $(\mathrm{C} 1, \mathrm{C} 6)$ or concern over (D7) nature, nature's central position as a meaning of the forest (C9) or merely nature's central position in a forest-owner's narration (C8) were all located on the positive end of this dimension, while the codes that represented indifference to nature (L16, L17) or critique of an ecologically oriented forest use (L5) were positioned on the negative end of the dimension. We thus interpreted Dimension 2 as a gradient from a weak to a strong human-nature relationship. Instead, Dimension 1 (x-axis) did not notably disperse the nature-related codes (Fig. 2).

Based on our earlier analysis of the ordination results, a strong relationship with nature appears to coincide with socio-cultural emphasis (emphasis on e.g. aesthetics, recreation, ambience and nostalgia for the past) and with a subordinate position in relation to the hegemonic economic truth of the forest and its proper use (Takala et al. 2017a, b). Similarly, a weak relationship with nature was connected to the economic orientation and to the hegemonic economic truth of the forest and its proper use (Takala et al. 2017a, b).

With regards to the five discourse types, most of the nature-related codes were typical of the discourses of the critical anti-economist, the dutiful forest-owner and the forester.

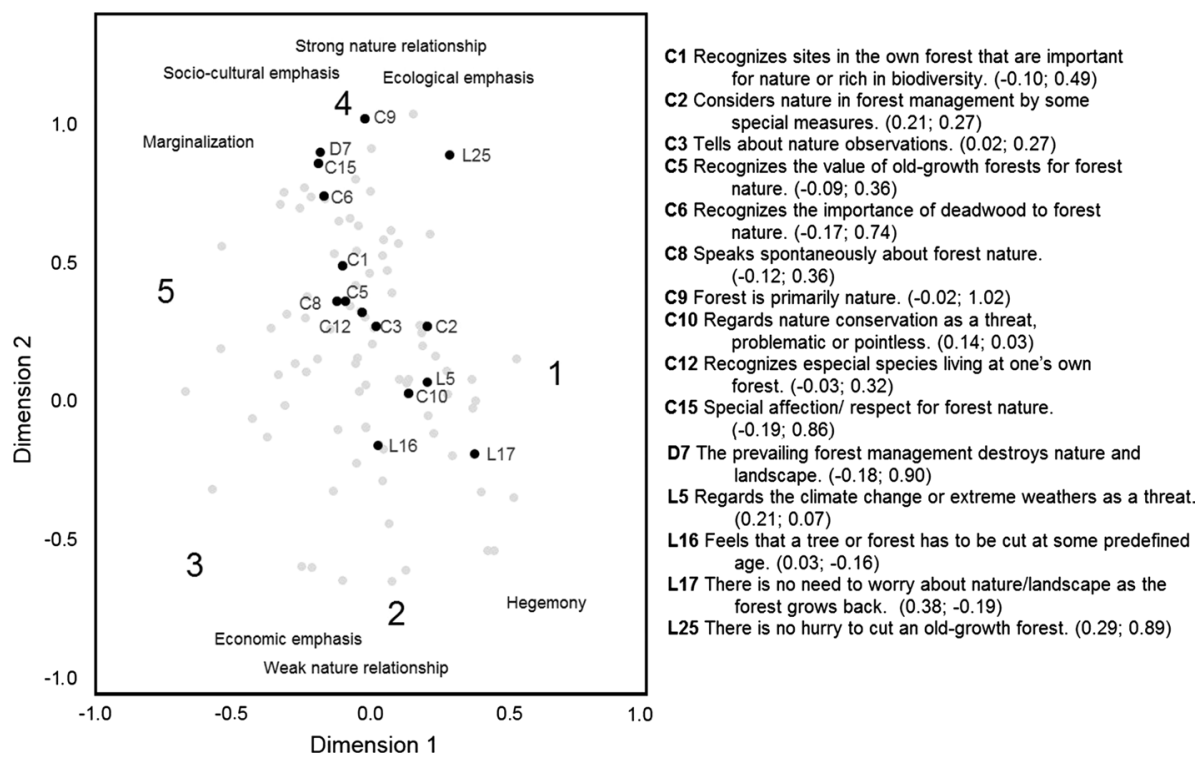

Fig. 2 Code positions in the NMS. The 15 nature-related codes are marked with black dots and labelled, while the other 83 codes included in the original analysis are presented as grey dots. The numbers $1-5$ indicate the approximate positions of the discourses of (1) the forester, (2) the economist, (3) the distant economist, (4) the critical anti-economist and (5) the dutiful forest-owner in the ordination space. The texts in the graph indicate the approximate ends of the gradients from a weak to a strong relationship with nature, an economic to a non-monetary (socio-cultural and ecological) emphasis (Takala et al. 2017a) and from hegemony to marginalisation (Takala et al. 2017b) 
Instead, the absence of these codes was an important feature of the discourses of the economist and the distant economist. The only two codes that were located near these last two discourses reflected indifference to nature, as they stressed properly timed loggings (L16) and the temporary nature of cutting effects (L17).

\section{Discourse types}

\section{Critical anti-economist}

See (Online Supplement A).

\section{Dutiful forest-owner}

See (Online Supplement B).

\section{Forester}

See (Online Supplement C).

\section{Economist and distant economist}

See (Online Supplement D).

\section{Discussion}

\section{Human-nature relationships within the five forest discourses}

Our analysis revealed that even if nature issues belong to many forest discourses in a cognitive and affective level, only one of them expressed such a concern over nature that could predict decisions to take responsibility for it. Even if we do not know the exact prevalence of the discourse types in the Finnish society, we can conclude that the concern and responsibility is definitely not shared by every Finnish forest owner. Against this background, the present biodiversity loss in the level of species (Hyvärinen et al. 2019, p. 41) and biotopes (Kouki et al. 2018) sounds understandable. When the gradient from an almost absent to a strong relationship with nature was the same as the gradient from an economic to a non-monetary orientation (Takala et al. 2017a), our results also illustrate how strong the polarization between the economic and the environmental orientation can be among Finnish forest-owners. The idea that a considerable share of Finnish forest-owners were multiobjective (Favada et al. 2009), and the high appreciation for nature found in forest-owner surveys (Horne et al. 2004; Paloniemi and Tikka 2008; Hallikainen et al. 2010) apparently tend to hide this deep polarisation. Berninger et al. (2009) concluded that the polarisation is typical of the societies with a long history of intensive forestry, like Finland, but they also found that a typical forest-owner is positioned near the economic pole.

The forester's and the dutiful forest-owner's relationships with nature were based on personal nature experiences and observations in the forest-owner's immediate surroundings. This reflects the way in which a layperson's relationship with nature is thought to be 
constructed (Pitkänen et al. 2011) and the way in which forest-owners are hypothesized to perceive abstract ecological concepts like biodiversity (Paloniemi and Tikka 2008).

Similarly, it has been hypothesized that the scientific ecological language does not match with the forest-owners' experienced-based understanding of the forest (Paloniemi and Tikka 2008; Pitkänen et al. 2011) and can even marginalise forest-owners (Berglund 2000). This possibly applies to the forester and the dutiful forest-owner. Instead, the experience-based narration on nature was complemented with an abstract ecological theorizing in the discourse of the critical anti-economist. We do not claim that the critical anti-economist would ponder metapopulation dynamics, extinction depth or deadwood continuum like an ecologist, but individual species' habitat requirements and general forest biodiversity were pondered at the level beyond personal experiences and observations. For the economist and distant economist type of forest owners, the exact form of ecological rhetoric is unimportant, as their motivation to receive and use this information is low anyway.

It has also been found in previous studies that, unlike an ecologist, a forest-owner's idea of biodiversity and conservation rarely extends beyond the estate boundaries (Fischer and Bliss 2009). Contrasting this, Paloniemi et al. (2018) discovered that some forest-owners stressed cross-boundary conservation issues, particularly, when this option was offered in the survey. In our analysis, the forester and the dutiful forest-owner were limited to their own estate in their experienced-based narration on nature, whereas the critical anti-economist stressed ecological issues beyond the property boundaries, even if the emphasis was in their own forest. This appeared, for example, in the critique of the standard even-aged forest management that was practiced, specifically, outside the forest-owner's own estate.

Importantly, we did not identify a purely ecologically oriented discourse type in this study. Good forest management and the forest-owner's own forest work were prioritized over nature in the discourse of the forester, whereas scenery and recreation possibilities were focused on in the discourse of the dutiful forest-owner (Takala et al. 2017a). The discourse of the critical anti-economist was the only one that prioritized nature, but tightly combined and intertwined that with the socio-cultural meanings of the forest. This possibly indicates that purely ecologically oriented forest-owners are rare in the Finnish countryside. In this sense, the mismatch between the forest-owners' understanding of the forest and the purely ecological rhetoric (Berglund 2000; Paloniemi and Tikka 2008) applies also to the critical anti-economist.

The economist's nearly absent relationship with nature highlights the need to make a conceptual delineation between the relationship with forest and the relationship with nature. A forest-owner can have a strong relationship with their forest without having nearly any relationship with species and biotopes. When the economist speaks or thinks about the forest, they do not usually make connotations to nature whereas this is normal and common for the critical anti-economist.

\section{The ecological consequences of the discourses}

\section{Nature and forest management}

Each of the forest discourses included an idea of proper forest management and a suggestion of how nature (forest species, biotopes, biodiversity) should be considered in the management. The critical anti-economist was the only ideal type that let ecological issues inform forest management. In the other four discourses, the needs of nature did not cause any major adjustments in the management proposed. In fact, all four of these discourses 
suggested very similar forest management: nature was considered by way of specific measures-like retention of individual broadleaf trees in thinning — but the practices overall followed the standard forest management guidelines and the accompanying ideal of effective wood production. By standard forest management we mean even-aged management with clear-cuttings which is still the predominant treatment type in Finnish forests, and which is quite the opposite for the close-to-nature forestry (following Bieling 2004). The forestry that would respond to the main reasons for the biodiversity loss - the lack of old-growth forests, old trees and deadwood, and the changes in tree-species composition (Hyvärinen et al. 2019, pp. 41-49)—could include light selection felling with low (economically suboptimal) wood production goals, considerably longer rotation times and, most importantly, setting some sites totally aside.

Especially in loggings, and particularly in the forests of the distant economist and the dutiful forest-owner, maintaining biodiversity was essentially left to those organizations and professionals that conducted the actual harvest planning and harvesting, emphasizing the role of forest companies and forest planning enterprises in biodiversity maintenance of private forests. The situation is not favourable for nature, as the principal aim of forest companies is, of course, wood acquisition. Despite the explicit political aim to integrate biodiversity conservation into standard forest management in recent decades, little has changed in practice (Primmer 2011). Deeply rooted professional norms guide individual professional foresters' practices in a hierarchical and uniform manner, making the organizational field resistant to any notable political changes and practical innovations (Primmer and Karppinen 2010). Therefore, our results support the view that despite the paradigm shift from timber production to multi-objective forestry in forest science and policy rhetoric in recent decades, the practical level forest management and planning lags behind in Fennoscandian private forestry (Fischer et al. 2010).

From the perspective of biodiversity maintenance, it was also concerning that the prevailing standard forest management was considered as nature-friendly enough in all but one forest discourse. This means that biodiversity problems caused by forestry practices do not exist for those forest owners who build their idea of the forest on these discourses. This positive stance and the idea that the forest-owner's practices have little effect on biodiversity seems to be rather common among forest-owners (Bieling 2004; Fischer and Bliss 2009), and Finns may have especially positive picture of the state of their environment because of a strong ecological self-identity (Sairinen 2001).

\section{The case of old-growth forests}

All of the discourses also suggested how a forest-owner should deal with an old-growth forest, an essential and diminishing (Punttila and Ihalainen 2006) environment for many red-listed species in Finland (Hyvärinen et al. 2019, pp. 47-49). In accordance with the ideal of effective wood production, all ideal forest-owners apart from the critical anti-economist agreed that an old-growth forest has to be cut before it deteriorates. This was the guiding principle also for the dutiful forest-owner and for the forester that, in rare occasions, saved parcels old-growth forests. Even the critical anti-economist was concerned about their old-growth forests despite the subordinate economic objectives. These results illustrate how deeply rooted and paradigmatic the idea of the necessity of human interventions for forest survival is among Finnish forest-owners. Climate change and the increased risk for bark beetle outbreaks in spruce monocultures have obviously strengthened this idea in recent years. 
From the perspective of critical discourse analysis, the strong concern over forest deterioration also reflects the hegemony of the economically-based and production-oriented truths of the forest (Takala et al. 2017b) and the marginalization of the idea of forests as an ecosystem. The prevailing order of the discourses set the critical anti-economist in a particularly unbeneficial position in relation to old-growth forests. The ecological and sociocultural values peak at the old-growth forests, whereas the social environment continuously promotes the importance of cutting these forests in time. This illustrates something that we could call "the conservationist's tragedy": the losses in forest function that cutting an oldgrowth forest causes cannot be restored within the life-span of the critical anti-economist. Instead, the economic and production-oriented forest functions valued by the economist and the forester are similarly present in forests of all ages.

\section{Policy recommendations}

Biodiversity loss continues despite the green rhetoric and diversifying forestry practices (Kouki et al. 2018; Hyvärinen et al. 2019, pp. 47-49, 111-112). This highlights the need for new perspectives and knowledge that can be used to guide a better forest policy. Our study revealed discoursal conditions in which both nature and the forest-owners that take responsibility for nature were marginalised. Biodiversity conservation could thus benefit from changing the prevailing order of the forest discourses or from strengthening the nature-oriented forest-owners' self-confidence as a forest-owner (Table 2). The latter way is probably an easier and faster one, as changes in the order of discourses are typically slow and difficult to steer (Fairclough 2010). Changing the order would necessitate that a forest-owner's whole semantic environment is moved towards a higher general appreciation for biodiversity and socio-cultural values in comparison with the economic and production-oriented ones. When a forest-owner's semantic environment covers at least the public media and all those people that interact with the forest-owner in forest issues, we can expect a slow change at best.

The critical anti-economist type of forest owner already takes nature and biodiversity into account in the forest use, but the concern over old-growth forests and the continuous comparison between the own and the hegemonic forest management (Takala et al. 2017b) indicate that this forest-owner type could invest still more time and thoughts to biodiversity conservation, if they would get more support for their forest-ownership and could feel more comfortable with their intertwined ecological and socio-cultural objectives (Table 2).

The dutiful forest-owner is an interesting type from the perspective of biodiversity conservation, as it may entail hidden potential for voluntary biodiversity enhancement in private forests. The adoption of forestry professionals' ideas on what the right type of forest management was caused a conflict between the forest-owner's socio-cultural objectives and the economically oriented forestry practices (Takala et al. 2017a, b). This kind of discrepancy between ideas and actions are not unprecedented within forest-owner studies (Bieling 2004; Pitkänen et al. 2011). Taking into account the convergence of the ecological and the socio-cultural forest meanings in this discourse, the dutiful forest-owner could be interested in a forest use that deviates from the ideal of effective wood production and creatively combines socio-cultural and ecological objectives. However, this necessitates that the dutiful forest-owner is first empowered to realize the whole potential decision space they would have without the marginalising effects of the hegemonic economic discourses (Takala et al. 2017 b). Forestry professionals, in particular, would have many opportunities to empower the dutiful forest-owner (Table 2), but this is apparently rare as the professionals denoted 


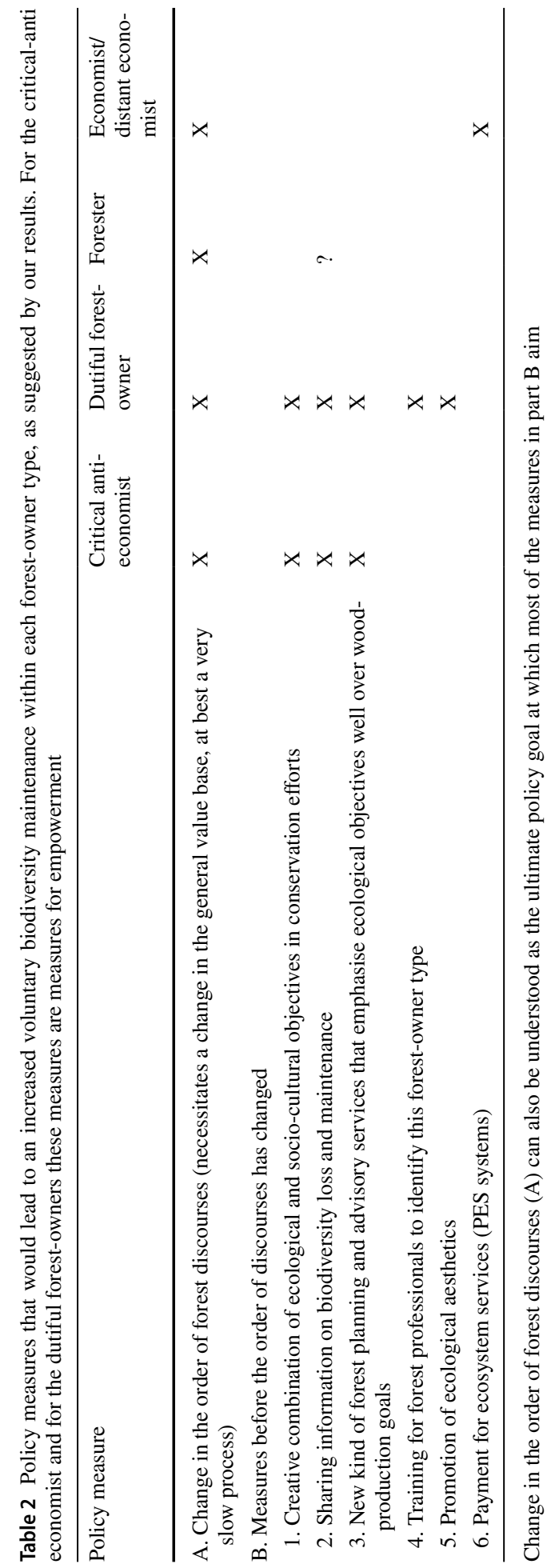


by the dutiful forest-owner typically work in organisations that advocate for traditional forestry and are not interested or capable of seeing beyond wood production. Thus, new kind of sensitivity for forest-owners' values and novel support mechanisms are thus needed within organisations who work with forest-owners.

We do not aim to deny the unavoidable conflicts that exist between some socio-cultural and ecological objectives (Gobster 1995). However, one of our main findings was that a genuine will to take both of these aspects into account, simultaneously, exists among those forest-owners who de-emphasise the forest's economic value. There is also a growing political will to make the forest sector both ecologically and socially more sustainable (Sheppard 2003; Bjärstig and Kvastegård 2016). Bringing ecological and socio-cultural goals closer to each other could also increase the popularity of conservation policy among forestowners (Fischer and Bliss 2009), especially among those who are socio-culturally but not ecologically oriented. The discrepancies between ecological and aesthetic objectives may also be at least partially counteracted by promoting ecological knowledge that could guide people towards ecological aesthetics (Table 2) i.e. the idea that a visual element or a scenery is beautiful if it has ecological value (Gobster 1995).

Potentials for a more nature-friendly forest ownership is apparently low within the discourses of the economist, the distant economist and the forester, and would demand a considerable change in the order of forest discourses (Table 2). The prevailing even-aged management paradigm supports the overall idea of the forest as an economic investment or wood production place in all of them. In this kind of situation, biodiversity maintenance is seen as a self-sacrificing activity rather than as a moral responsibility (Fischer and Bliss 2009).

The forester could be especially non-responsive to any biodiversity-enhancing initiatives because of the pronounced and prioritized idea of the proper economic and productionoriented forest management (Table 2). This discourse can be seen to reflect the traditional national-romantic paradigm that praises human work in a harmonious co-operation with nature (Berglund 2000; Sairinen 2001; Silvasti 2003; Pitkänen et al. 2011). Paradoxically, the idea of the necessity of human interventions has made this paradigm blind to many environmental problems it has caused (Silvasti 2003). The increase of deadwood necessary for many forest species would, for example, essentially violate the ideal of this paradigm (Paloniemi and Vilja 2009). The economist and the distant economist could actually be more responsive to biodiversity-enhancing changes on the condition that these changes were subsidized enough to make them economically tempting in relation to prevailing forest management practices (Table 2).

However, we found some interesting variation in the human-nature relationship within the discourse of the forester. In the non-monetary end of this discourse, the nature around was both observed and appreciated. The discourse just excluded threats for nature, like did the discourse of the dutiful forest owner. If a forest owner builds their worldview on these discourses, they are not responsive for information on these threats and, consequently, awareness of biodiversity loss remains low. We do not know whether this appreciation for nature could be developed into the responsibility for nature by adding targeted information in a right form and from right sources (Table 2). The major barriers for this change, depicted in the previous paragraph, apply also to a nature-oriented forester, whereas a dutiful forest owner could be more responsive.

Finally, it is worth emphasizing that the popularity of official forest protection (establishment of nature reserves) among the ideal forest-owners is out of our reach in this study. This issue was addressed in the 24 narrations only occasionally and forest protection played a minor role in the discourses. Official forest protection is an especially complex 
and conflict-sensitive issue (Tikka and Kauppi 2003; Hiedanpää 2005; Bergseng and Vatn 2009) that seems to be, as its absence in the discourses suggests, distant or distancing for most of the forest-owners. The critical anti-economist, for example, may be unwilling to protect an old-growth forest officially despite their ecological emphasis, as there was a need to keep all aspects of decision making in the hands of the forest-owner. Independent, cross-generational decision-making and property rights are highly valued by Finnish forestowners (Rekola et al. 2000; Horne et al. 2004) and only few of them are typically interested in the official protection of their land. This is evidenced in multiple surveys (Horne et al. 2004; Paloniemi and Tikka 2008). In fact, environmentally oriented forest-owners may also refuse to protect officially from ideological reasons, if this kind of protection is seen as an utilitarian activity because of economic incentives (Primmer et al. 2014).

\section{Theoretical and methodological considerations}

Based on our experiences in this study, it is easy to recommend critical discourse analysis for the conservation sciences. It can reveal fundamental power structures that hinder effective biodiversity conservation and would remain invisible with other methods. The analysis of human-nature relationships within the wider forest discourses is another feature of this paper that we regard as promising and potentially useful in other land-use contexts. It seems that the human tendency to give politically correct and socially acceptable answers (Ficko and Bončina 2014) was counteracted effectively when the forest-owners were free to speak or not speak about nature issues.

However, application of critical discourse analysis in the conservation sciences also needs some theoretical development. It is important to include the responsibility for nature into the explicit ethical commitments of critical discourse analysis in addition to the traditional social commitment. This necessitates that nature or some of its components, like specific species, are treated as subjects that can be marginalised in discoursal struggle. Nevertheless, we have to acknowledge that nature cannot be included in the analysis as human subjects are-many concepts like empowerment are barely applicable for nature.

In the studies like this that are based exclusively on linguistic narrations and representations, it is impossible to make exact conclusions of the material effects of discourses. At the same time, the value of a discourse analysis often depends on these "external" references and their capacity to facilitate a reader's understanding of the material and other nondiscoursal parts of reality. Certainly, excessively courageous references to the non-discoursal reality form a weak spot in the discourse analysis. One way to bridge the gap between the material and discoursal realms is to add some ecological measures or measures of forest-owners' realized management practices into the analysis. This would move an analysis towards the theory of social-ecological systems (e.g. Lischka et al. 2018). In fact, it would be quite new for social-ecological systems research to analyse how competing discourses affect ecological parameters through forest-owners' activities.

Our in-depth analysis of the small stratified random sample of forest-owners' narratives ( $n=11$ for the owners $\leq 5$ ha, $n=13$ for the owners $>5$ ha) was not designed to assess the exact proportions of the discourse types in Finnish society, but to develop understanding on how competing discourses of the forest guide forest owners' ideas about nature and biodiversity conservation. However, we also encourage conservation social scientists to measure the exact prevalence of discourse types in societies after these have been identified with indepth qualitative or mixed methods. 


\section{Conclusions}

Our analysis drew a relatively dark but, as we have reason to assume based on the current biodiversity problems, realistic picture of Finnish forest-owners' readiness for a proactive, intrinsically motivated biodiversity conservation. However, there are also untapped potentials for a more sustainable future. Biodiversity conservation could essentially benefit from making the society more receptive not only to ecological but also to socio-cultural ideas of the forest, as the socio-cultural and the ecological meanings of forest are both suppressed by the hegemonic economic idea of the forest. The socio-cultural forest values could also demand conservation in their own terms, as "the sense of forest" seems to be threatened by the decrease of old-growth forests. The marginalised nature-oriented forest-owners would also need more support for their forest-ownership. Examination of biodiversity issues through the lenses of critical discourse analysis seems highly promising, and we recommend this kind of approaches wherever private landowning is important for biodiversity maintenance.

Acknowledgements Open access funding provided by University of Eastern Finland (UEF) including Kuopio University Hospital. We warmly thank Kone Foundation for financial support, Prof. Ari Lehtinen for valuable comments, Rebekah Zimmerer for technical support, and the forest-owners who kindly attended to this study.

Open Access This article is distributed under the terms of the Creative Commons Attribution 4.0 International License (http://creativecommons.org/licenses/by/4.0/), which permits unrestricted use, distribution, and reproduction in any medium, provided you give appropriate credit to the original author(s) and the source, provide a link to the Creative Commons license, and indicate if changes were made.

\section{References}

Arnold JS, Koro-Ljungberg M, Bartels W-L (2012) Power and conflict in adaptive management: analyzing the discourse of riparian management on public lands. Ecol Soc 17(1):19

Bennett NJ et al (2017) Mainstreaming the social sciences in conservation. Conserv Biol 31:56-66

Berglund E (2000) Forestry expertise and national narratives: some consequences for old growth conflicts in Finland. Worldviews 4:47-67

Bergseng E, Vatn A (2009) Why protection of biodiversity creates conflict-some evidence from the Nordic countries. J For Econ 15:147-165

Berninger K, Kneeshaw D, Messier C (2009) The role of cultural models in local perceptions of SFM-differences and similarities of interest groups from three boreal regions. J Environ Manage 90:740-751

Bieling C (2004) Non-industrial private forest owners: possibilities for increasing adoption of close-tonature forest management. Eur J For Res 123:293-303

Bjärstig T, Kvastegård E (2016) Forest social values in a Swedish rural context: the private forest owners' perspective. For Policy Econ 65:17-24

Butler BJ, Hewes JH, Dickinson BJ, Andrejczyk K, Butler SM, Markowski-Lindsay (2016) USDA Forest Service National Woodland Owner Survey: national, regional, and state statistics for family forest and woodland ownerships with 10+acres, 2011-2013. Res Bull NRS-99, p 39. http://www.nrs.fs.fed.us/ pubs $/ 50674$

Castree N (2014) Making sense of nature. Routledge, Oxon, p 347

Crandall SG et al (2018) Best practices: social research methods to inform biological conservation. Australas J Env Man 25(1):6-23

Eriksson L (2012) Exploring underpinnings of forest conflicts: a study of forest values and beliefs in the general public and among private forest owners in Sweden. Soc Nat Resour 25:1102-1117

Fairclough N (2010) Critical discourse analysis. The critical study of language, 2nd edn. Pearson Education Limited, Harlow, p 608 
Favada IM, Karppinen H, Kuuluvainen J, Mikkola J, Stavness C (2009) Effects of timber prices, ownership objectives, and owner characteristics on timber supply. For. Sci. 55:512-523

Ficko A, Bončina A (2014) Ensuring the validity of private forest owner typologies by controlling for response style bias and the robustness of statistical methods. Scand J For Res 29:210-223

Finnish Statistical Yearbook of Forestry (2014) Finnish Forest Research Institute, Vantaa, Finland, p 426 (in Finnish with English abstract, figures and tables). http://stat.luke.fi/mets\%C3\%A4tilastollinen-vuosi kirja-2014-2003_fi

Fischer AP, Bliss JC (2009) Framing conservation on private lands: conserving oak in Oregon's Willamette Valley. Soc Nat Resour 22:884-900

Fischer AP, Bliss J, Ingemarson F, Lidestav G, Lönnstedt L (2010) From the small woodland problem to ecosocial systems: the evolution of social research on small-scale forestry in Sweden and the USA. Scand J For Res 25:390-398

Flint CG, Kunze I, Muhar A, Yoshida Y, Penker M (2013) Exploring empirical typologies of human-nature relationships and linkages to the ecosystem services concept. Landsc Urban Plan 120:208-217

Gobster PH (1995) Aldo Leopold's ecological aesthetic: integrating esthetic and biodiversity values. J For 93:6-10

Hallikainen V, Hyppönen M, Pernu L, Puoskari J (2010) Family forest owners' opinions about forest management in Northern Finland. Silva Fenn 44(2):363-384

Hiedanpää J (2005) The edges of conflict and consensus: a case for creativity in regional forest policy in Southwest Finland. Ecol Econ 55:485-498

Holmgren S, Arora-Jonsson S (2015) The Forest Kingdom-with what values for the world? Climate change and gender equality in a contested forest policy context. Scand J For Res 30:235-245

Horne P, Koskela T, Ovaskainen V (2004) Safeguarding forest biodiversity in Finland-citizens' and non-industrial private forest owners' views. Metsäntutkimuslaitoksen tiedonantoja 933:1-110 (in Finnish with an English abstract.)

Hyvärinen E, Juslén A, Kemppainen E, Uddström A, Liukko U-M (eds) (2019) The 2019 red list of finnish species. Ministry of the Environment \& Finnish Environment Institute, Helsinki, p 704 (in Finnish with an English abstract). https://www.environment.fi/redlist

Juslén A, Pykälä J, Kuusela S, Kaila L, Kullberg J, Mattila J, Muona J, Saari S, Cardoso P (2016) Application of the Red List Index as an indicator of habitat change. Biodivers Conserv 25:569-585

Kouki J, Junninen K, Mäkelä K et al. (2018) Metsät [Forests]. In: Kontula T and Raunio A (eds) Threatened habitat types in Finland 2018, Red list of habitats, part I: results and basis for assessment. The Finnish Environment 5/2018. pp. 171-201 (in Finnish with an English abstract). https://www. ymparisto.fi/fi-FI/Luonto/Luontotyypit/Luontotyyppien_uhanalaisuus/Luontotyyppien_uhanalaisu us_2018

Leipold S (2014) Creating forests with words - a review of forest-related discourse studies. For Policy Econ 40:12-20

Lidestav G, Sjölander AE (2007) Gender and forestry: a critical discourse analysis of forestry professions in Sweden. Scand J For Res 22:351-362

Lischka SA, Teel TL, Johnson HE, Reed SE, Breck S, Carlos AD, Crooks KR (2018) A conceptual model for the integration of social and ecological information to understand human-wildlife interactions. Biol Conserv 225:80-87

Luke (2018) Forest resources by region. https://stat.luke.fi/en/forest-resources. Accessed 28 Nov 2018

McCune B, Grace JB (2002) Analysis of Ecological Communities. Gleneden beach, MjM Software, p 304

Ministry of Agriculture and Forestry (2014) Forest Act 1096/1996, amendments up to 567/2014. Available at: https://www.finlex.fi/fi/laki/kaannokset/1996/en19961093.pdf. Accessed 12 Aug 2019

Ministry of Agriculture and Forestry (2015) National Forest Strategy 2025. Government Resolution of 12 February 2015. Available at: http://mmm.fi/kms. Accessed 12 Aug 2019

Mitani Y, Lindhjem H (2015) Forest owners' participation in voluntary biodiversity conservation: what does it take to forgo forestry for eternity? Land Econ 91:235-251

Nzau JM, Rogers R, Shauri HS, Rieckmann M, Habel JC (2018) Smallholder perceptions and communication gaps shape East African riparian ecosystems. Biodivers Conserv 27:3745-3757

Paloniemi R, Tikka PM (2008) Ecological and social aspects of biodiversity conservation on private lands. Environ Sci Policy 11:336-346

Paloniemi R, Vilja V (2009) Changing ecological and cultural states and preferences of nature conservation policy: the case of nature values trade in South-Western Finland. J Rural Stud 25:87-97

Paloniemi R, Hujala T, Rantala S, Harlio A, Salomaa A, Primmer E, Pynnönen S, Arponen A (2018) Integrating social and ecological knowledge for targeting voluntary biodiversity conservation. Conserv Lett 11(1): 12340 
Pitkänen K, Puhakka R, Sawatzky M (2011) The role of nature in the place meanings and practices of cottage owners in northern environments. Nor Geogr Tidsskr 65:175-187

Primmer E (2011) Analysis of institutional adaptation: integration of biodiversity conservation into forestry. J Clean Prod 19:1822-1832

Primmer E, Karppinen H (2010) Professional judgment in non-industrial private forestry: forester attitudes and social norms influencing biodiversity conservation. For Policy Econ 12:136-146

Primmer E, Paloniemi R, Similä J, Tainio A (2014) Forest owner perceptions of institutions and voluntary contracting for biodiversity conservation: not crowding out but staying out. Ecol Econ 103:1-10

Pulla P, Schuck A, Verkerk PJ, Lasserre B, Marchetti M, Green T (2013) Mapping the distribution of forest ownership in Europe. EFI Tech. Rep. 88, p 91, Available at: https://www.efi.int/publications-bank/ mapping-distribution-forestownership-europe

Punttila P, Ihalainen A (2006) Luonnontilaisen kaltaiset metsät suojelu- ja ei-suojelluilla alueilla. In: Horne P, Koskela T, Kuusinen M, Otsamo A, Syrjänen K (eds) Metson jäljillä. Etelä-Suomen metsien monimuotoisuusohjelman tutkimusraportti. Maa- ja metsätalousministeriö, ympäristöministeriö, Metsäntutkimuslaitos ja Suomen ympäristökeskus, Vammala, pp 19-20. (in Finnish)

Rekola M, Pouta E, Kuuluvainen J, Tahvonen O, Li CZ (2000) Incommensurable preferences in contingent valuation: the case of Natura 2000 Network in Finland. Environ Conserv 27:260-268

Sairinen R (2001) Public support for environmental policy in Finland: cultural interpretations of survey results. Scand Polit Stud 24:129-148

Sheppard S (2003) Knowing a socially sustainable forest when you see one: implications for results-based forestry. For Chron 79:865-875

Silvasti T (2003) The cultural model of "the good farmer" and the environmental question in Finland. Agric Human Values 20:143-150

Smith PM (2006) The application of critical discourse analysis in environmental dispute resolution. Ethics Place Environ 9:79-100

Sumares D, Fidélis T (2011) Natura 2000 and the narrative nature of nature: a case for critical discourse analysis. J Integr Environ Sci 8:53-68

Sundberg J, Dempsey J (2009) Culture/Natures. In: Kitchin R, Thrift N (eds) International Encyclopedia of Human Geography. Elsevier, Amsterdam, pp 458-463

Takala T, Hujala T, Tanskanen M, Tikkanen J (2017a) Forest owners' discourses of forests: ideological origins of ownership objectives. J Rural Stud 51:1-14

Takala T, Hujala T, Tanskanen M, Tikkanen J (2017b) The order of forest owners' discourses: hegemonic and marginalised truths about forest and forest ownership. J Rural Stud 55:33-44

Taylor CS, Carter J (2013) The agency of dolphins: towards inter-species embassies as sites of engagement with 'Significant Otherness'. Geogr Res 51(1):1-10

Teel TL et al (2017) Publishing social science research in conservation biology to move beyond biology. Conserv Biol 32:6-8

Tikka PM, Kauppi P (2003) Introduction to special issue: protecting nature on private land-from conflicts to agreements. Environ Sci Policy 6:193-194

Vainio A, Paloniemi R, Hujala T (2018) How are forest owners' objectives and social networks related to successful conservation? J Rural Stud 62:21-28

van Dijk TA (1993) Principles of critical discourse analysis. Discourse Soc. 4:249-283

Zorondo-Rodríguez F, Reyes-García V, Simonetti JA (2014) Conservation of biodiversity in private lands: are Chilean landowners willing to keep threatened species in their lands? Rev Chil Hist Nat 87:4

Publisher's Note Springer Nature remains neutral with regard to jurisdictional claims in published maps and institutional affiliations.

\section{Affiliations}

\section{Tuomo Takala $^{1}$ (D) Teppo Hujala ${ }^{1,2} \cdot$ Minna Tanskanen $^{3} \cdot$ Jukka Tikkanen $^{1}$}

Teppo Hujala

teppo.hujala@luke.fi; teppo.hujala@uef.fi

Minna Tanskanen

minna.tanskanen@uef.fi 
Jukka Tikkanen

jukka.tikkanen@uef.fi

1 Faculty of Science and Forestry, School of Forest Sciences, University of Eastern Finland, 80101, P.O. Box 111, Joensuu, Finland

2 Natural Resources Institute Finland (Luke), Bioeconomy and Environment, Latokartanonkaari 9, 00790 Helsinki, Finland

3 Department of Geographical and Historical Studies, Faculty of Social Sciences and Business Studies, University of Eastern Finland, P.O. Box 111, 80101 Joensuu, Finland 